\title{
Coastal landscape changes pattern due to natural disasters in Pelabuhanratu District, West Java
}

\author{
Mufidah Tartila ${ }^{1, *}$, Supriatna ${ }^{1}$, Masita Dwi Mandini Manessa ${ }^{1}$, and Yoanna Ristya $^{1}$ \\ ${ }^{1}$ Departement of Geography, Faculty of Mathematics and Natural Sciences, University of Indonesia, Depok - Indonesia.
}

\begin{abstract}
The concept of landscape is known to be always changing dynamically because of its attachment to natural and human activities that continue to grow over time. The aim of this study is to identify landscape changes from 2010 to 2018 which are associated with natural disaster events. Coastal area is the study target on landscape changes due to natural disasters. The research took place in Pelabuhanratu District, Sukabumi Regency which is known for its varied geomorphological form and its natural disaster events occurrence including coastal floods, flash floods, and landslides. The research data was processed using ArcGIS 10.4.1 and ENVI 5.1 software. Data verification was done by field surveys in the study area. The method of this study is an overlay analysis and explained in the term of spatial dan descriptive concept. The landscape of Pelabuhanratu District is dominated by volcanic landforms and vegetation cover. The total area experiencing landscape changes is $44.47 \mathrm{~km} 2$ of the district total area of $91.91 \mathrm{~km} 2$ and major changes are involving alteration of land cover area.
\end{abstract}

Keywords: Coastal landscape; landform; landcover; Pelabuhanratu District

\section{Introduction}

Landscape, in geographical terms, is related to geomorphology and human activities which construct the forming of the earth's surface spatial characteristics. Indonesia is located between three tectonic plates (Eurasia, Indo-Australia, and the Pacific Ocean) which cause the limitless geomorphological forms to all-region throughout the country. That makes Indonesia is adequately convenient to be used as an object of analysis related to the landscape. Indonesia is known for its marine resources due to its coastal area. The concept of landscapes in Indonesia has begun to be widely used, especially for coastal management. One of the Coastal areas with various characteristics in terms of landscape is Pelabuhanratu District of Sukabumi, West Java. Pelabuhanratu District is experiencing various natural disasters over years and this might affect its landscape changes in particular ways.

The concept of landscape is known to be always changing dynamically because of its attachment to natural and human activities that continue to grow over time. This study aims to identify landscape changes that are associated with natural disaster events. Geography plays a role in analyzing spatial patterns of landscape changes and how natural disaster events affect them.

\section{The Concept of Coastal Landscape}

Landscapes are interpreted differently depending on one's background. Zinck [1] explains that landscapes are generally interpreted as a view of the earth's surface or its visual representation. The word landscape is first defined as a way of looking at something [2]. Cosgrove and Daniels (1988) [2] complement that landscapes are a complex way of looking at the world so that it creates an interesting view. Landscapes are influenced by physical and human aspects. In this study, the physical aspects include landforms and human aspects represented by landcover. Landscape classifications can be generated by combining landscape attributes to produce landscape classes that are the unique combinations of these attributes [3]. The landscape attributes in this study are landform and landcover, so landscape classifications in this study were made based on landform and landcover overlay results.

Coastal landscapes mean that they are related to the environment in coastal areas. Coastal areas include river valleys, river mouths, sea borders, to continental basins [4]. The landform of coastal land is not always the same in each region depending on the elements that play a role in its forming process. To this day, there are still no valid agreements between experts regarding coastal bounds and it's always been debatable. Bengen [5] explains that coastal bounds can be identified based on three boundaries, the first is the transition zone of land and sea that is directly affected by tides, the second is based on the administrative boundaries of the village or subdistrict bordering the coast, and the third is based on ecological conditions, which is interpreted as a crossline between terrestrial and marine ecosystems.

* Corresponding author: mufidah.tartila@ui.ac.id 
Geomorphology is representing physical aspect of landform. The concept of geomorphology is important for landscape analysis because it represents the main parameters that determine the land spatial configuration and facilitate the classification of [6]. Geomorphology is the science of systematic study of landforms and their origin [7]. According to Van Zuidam [8], there are four aspects that arrange the concept of geomorphology, which are morphology, morphogenesis, morphochronology, and morpho-arrangement. Morphology is relief of surface of the earth consisting of Morphometry and Morphography. Morphometry is an element of the parameters that is expressed in units of measure (quantitative) which includes slopes and heights. Morphography is an element that is expressed descriptively (qualitatively), which includes the shape on the land. Morphogenesis is the process of formation and development of landforms. Morpho-chronology is the stage of land formations. Morpho-arrangement is the relationship between a landform and the surrounding environmental conditions which are presented in spatial terms. The map model of geomorphology can be created by combining morphological (terrain) and morphogenetical (origin form) aspects.

Landcover becomes a representation for human aspect of land forming. There's one third to half of the land surface has changed due to human activities. Landcover will continue to develop and change as long as humans settle in the area. The denser the population that occupies an area, the more human activity will be occurred.

\section{Methods}

\subsection{Study Area}

The research area is Pelabuhanratu, Sukabumi Regency, West Java. Pelabuhanratu is a district in Sukabumi Regency which is directly adjacent to Indian Ocean. Pelabuhanratu is the capital of Sukabumi Regency, Pelabuhanratu City consists of 10 villages, namely Buniwangi, Cibodas, Cikadu, Cimanggu, Citarik, Citepus, Jayanti, Pasirsuren, Tonjong, and Palabuhanratu with the total administration of $91.90 \mathrm{~km}^{2}$ in width. Though the Pelabuhanratu District is well-known by its beaches, the landform itself is generally dominated by hills and mountains.

Sukabumi Regency is an area located around active volcanoes and varies in geological structures. Therefore, Pelabuhanratu City basically consists of volcanic and structural origin. The city of Pelabuhanratu is also an area that is traversed by many rivers flowing into Pelabuhanratu Bay, and that makes some parts of the area consists of fluvial origin forms. The land cover in the city of Pelabuhanratu consists of water bodies, forests, scrubs, plantations, built-up lands, and agricultural lands. Because the relief form of Pelabuhanratu consists of the dominance of hills and mountains, the land cover is dominated by vegetation which includes forests, scrubs, and plantations.

\subsection{Data Processing}

Data collecting is done through observation, interviews, and also through agencies. The collected data was entirely modified in the form of spatial data. The data that has been collected for this study were processed using ArcMap 10.4.1 and ENVI 5.1 softwares to be displayed in the form of maps so that they can be analyzed in spatial terms. All spatial data used in the processing are first adjusted in an UTM projection, which 1984 WGS UTM $48 \mathrm{~S}$ which is where the study area is located. This step was done with the aim of facilitating the calculation of the area needed later in data analysis.

The landform map is obtained from the results of overlay between the terrain map (generated from slope and elevation map) and the original form map (generated from geological map). Polygon formed then adjusted its characteristics based on the classification of landform units according to Van Zuidam [8] in order to produce spatial data on landforms.

Imagery data is needed in the year 2010 and 2018 to generate image classification and show the changes in landcover patterns. This land cover map was made with the intention of becoming the representation of human activities that would shape the landscape when overlaid with landform maps. Image classification for land cover is applied using supervised techniques and adjusted to the provisions of the classification of Indonesian National Standard Landcover (SNI) No. 7645-1: 2014 [9].

\section{Results}

\subsection{Natural Disasters in Pelabuhanratu}

Based on data from the BPBD of Sukabumi Regency and information from residents in Pelabuhanratu District, there were 16 natural disaster occurrences from 2010 to 2018 which included 13 landslide points, 2 coastal flood points, and 1 flash flood point. Disasters occurred in 5 villages, namely Cikadu, Cimanggu, Citepus, Jayanti, and Palabuhanratu. Landslides occurred in Cikadu, Cimanggu, Citepus, and Palabuhanratu. Flash floods occur in Palabuhanratu. A coastal flood occurs in Citepus and Jayanti.

\subsection{Landscape Changes of Pelabuhanratu}

Based on Van Zuidam's classifications, Pelabuhanratu is resulting in five kinds of landforms. There are floodplains (F3), volcanic plains (V8), fluvial terraces (F6), volcanic slope (V3), layered rock hills (S4). Floodplains (F3) in Pelabuhanratu City are landforms formed from fluvial processes and the shape 

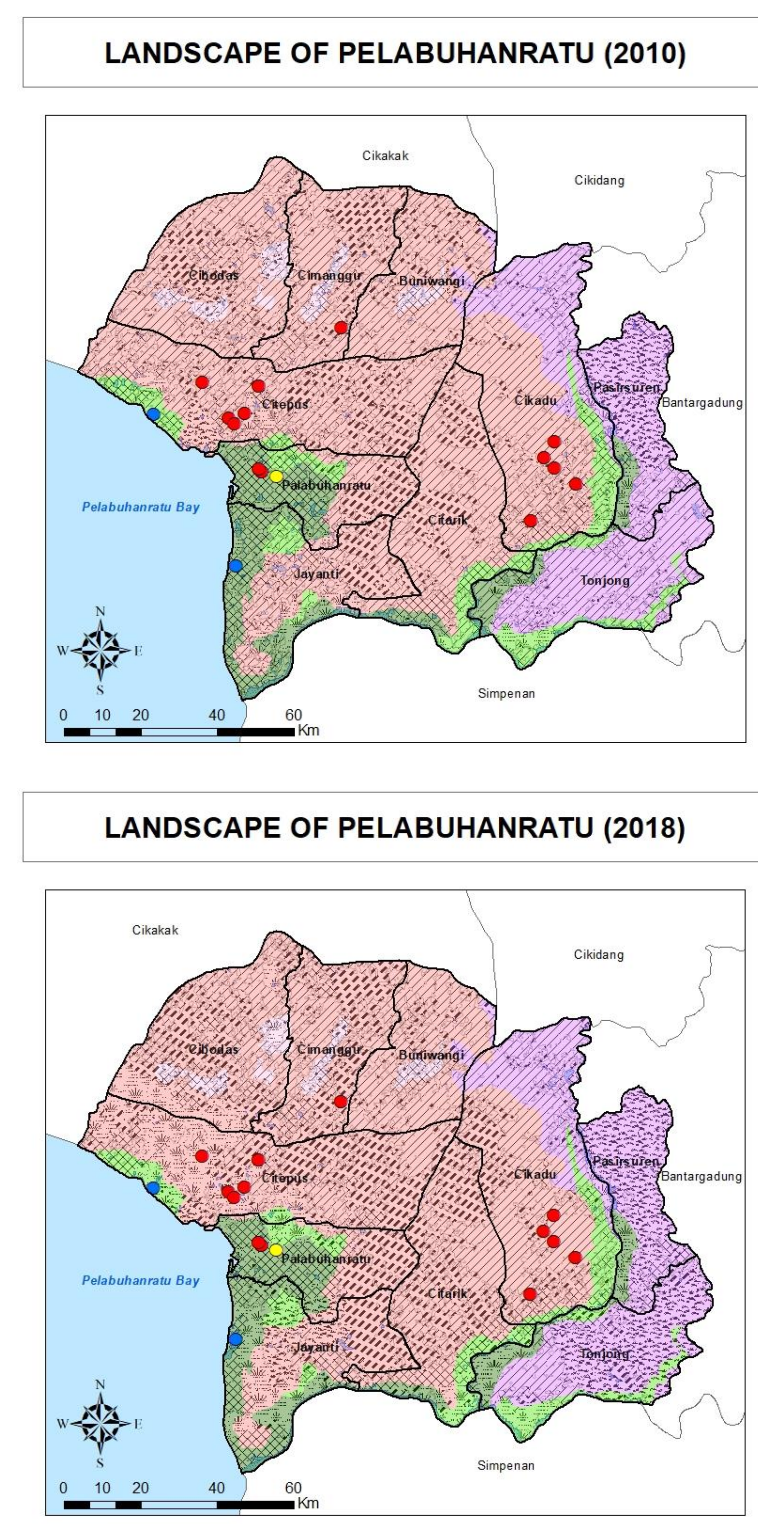

\section{Flash floods \\ - Coastal floods \\ - Landslides}

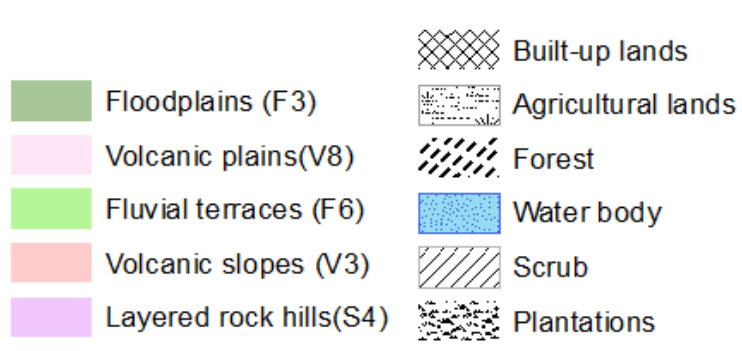

Fig. 1. Landscape of Pelabuhanratu.

of the terrain tends to be flat. This form of land is characterized by seasonal flooding around the area. Volcanic Plain (V8) in Pelabuhanratu District is a region with topography and gentle slopes with the formation of the origin of volcanic processes. This region is inserted between mountains and hills with the dominance of land cover in the form of built-up land (settlements). Fluvial terraces (F6) is a landform with a fluvial process with gentle sloping topography and erosion by rivers. The volcanic slope (V3) is a collection of hills and mountains with medium to steep slopes. Most landcover in this area is vegetation in the form of shrubs and forests. The mountains contained in this landform include Mount Batu, Mount Mangge, Mount Jayanti and Mount Gadog. Layered rock hills (S4) are structural origin landforms with geological structures including synclines, anticlines, and shear faults. Landcover types that cover each landform are variated in width so that they are resulting in a spatial pattern. The width comparison is shown in Table 1. and the result of the overlaid maps and the disaster events are shown in Fig. 1. Landscape changes only occur on land cover, while the landform shows no significant changes.

Table 1. Landcover width comparison on each landform in 2010 and 2018 (km2). BL = Built-up Lands; $\mathrm{AL}=$

Agricultural Lands ; $\mathrm{F}=$ Forest $; \mathrm{WB}=$ Water Body $; \mathrm{S}=$ Scrubs $; \mathrm{P}=$ Plantations $; \mathrm{F} 3=$ Floodplains $; \mathrm{V} 8=$ Volcanic Plains ; F6 = Fluvial Terraces $;$ V3 = Volcanic Slopes ; S4 = Layered Rock Hills.

\section{Landscape}

\begin{tabular}{|c|c|c|c|r|r|r|}
\hline Attributes & F3 & V8 & F6 & V3 & \multicolumn{1}{c|}{ S4 } & Total \\
\hline BL & 4.13 & 0.52 & 2.37 & 4.91 & 1.44 & 13.37 \\
\hline AL & 1.96 & 0.06 & 1.11 & 1.74 & 0.43 & 5.3 \\
\hline F & 0.02 & 0.15 & 0.08 & 13.85 & 0.86 & 14.96 \\
\hline WB & 0.67 & 0.05 & 0.52 & 0.32 & 0.2 & 1.76 \\
\hline S & 1.01 & 0.86 & 2.09 & 33.41 & 9.83 & 47.2 \\
\hline P & 0.13 & 0.24 & 0.31 & 4.63 & 4.03 & 9.34 \\
\hline Total & 7.91 & 1.87 & 6.47 & 58.87 & 16.79 & $\mathbf{9 1 . 9 1}$ \\
\hline
\end{tabular}

2018 Landscape

\begin{tabular}{|c|c|c|c|r|r|r|}
\hline Attributes & F3 & V8 & F6 & V3 & S4 & Total \\
\hline BL & 3.71 & 0.59 & 1.84 & 6.18 & 1.78 & 14.1 \\
\hline AL & 2.77 & 0.15 & 1.8 & 6.09 & 0.24 & 11.05 \\
\hline F & 0.35 & 0.4 & 0.56 & 21.49 & 1.47 & 24.27 \\
\hline WB & 0.5 & 0 & 0.41 & 0.15 & 0.26 & 1.32 \\
\hline S & 0.37 & 0.73 & 1.01 & 23.46 & 5 & 30.57 \\
\hline P & 0.22 & 0 & 0.85 & 1.49 & 8.05 & 10.61 \\
\hline Total & 7.91 & 1.87 & 6.47 & 58.87 & 16.79 & $\mathbf{9 1 . 9 1}$ \\
\hline
\end{tabular}

At the point of coastal flooding in the Citepus and Jayanti, changes that were spotted is the landscape of Floodplains/Built-up Lands into Floodplain/Agricultural Lands. Coastal floods carry several negative impacts on residents' houses (built-up lands). Coastal flood caused puddles on the ground and resulting damages to houses and other buildings. In addition, coastal floods result in increased groundwater salinity, so that groundwater, which is the main source of clean water for the people of Pelabuhanratu District, becomes inadequate. As a result of the impact of the tidal flood, management costs are needed for the government to maintain the land to support the activity center in Pelabuhanratu, and this will be financially detrimental. Therefore, the buildings were forced to be allocated to safer areas and a bit far from the 
coast. The land is now utilized as agricultural land. The area is suitable to be used as agricultural land because there are types of alluvial deposits that can fertilize farm produce. In addition, because it is located near the beach, irrigating rice fields can utilize tide from the sea. This strategy is beneficial to the community.

Other changes were spotted in Citepus at the points of landslides, from volcanic slopes/scrubs into volcanic slopes/agricultural lands. The loss of vegetation caused by landslides in Citepus generates the need for the land to be replanted so that it prevents other landslides from reoccurring. Therefore, dry land (fields) were built as anticipation so that landslides did reoccur in the same location. Some areas around former landslides have also been filled with bushes again. Landslides in Cikadu experienced changes in land cover from forest to bush. This may occur due to reduced vegetation naturally due to landslides, or replanting plants to cover empty land after a landslide. The total changes are shown in Figure 2.

Table 2. Landscape changes width.

\begin{tabular}{|r|r|}
\hline \multicolumn{1}{|c|}{ Landscape Changes } & Area $\left(\mathbf{k m}^{2}\right)$ \\
\hline Changed due to disasters & 4,08 \\
\hline Changed due to other causes & 41,37 \\
\hline Didn't change & 46,45 \\
\hline Total & $\mathbf{9 1 , 9 1}$ \\
\hline
\end{tabular}

Table 3. Landscape Changes due to Natural Disaster events.

\begin{tabular}{|c|c|c|c|c|c|}
\hline \multirow{2}{*}{ No. } & \multirow{2}{*}{ Disaster Type } & \multicolumn{2}{|c|}{ Coordinates } & \multirow{2}{*}{ Village } & \multirow{2}{*}{$\begin{array}{c}\text { Landscape } \\
\text { Changes } \\
\end{array}$} \\
\hline & & $\mathbf{Y}$ & $\mathbf{X}$ & & \\
\hline 1 & Coastal Flood & -6.9658 & 106.5405 & Citepus & Changed \\
\hline 2 & Coastal Flood & -6.9726 & 106.6721 & Jayanti & Changed \\
\hline 3 & Flash Flood & -6.9809 & 106.6088 & Palabuhanratu & Didn't change \\
\hline 4 & Landslide & -6.9849 & 106.5482 & Palabuhanratu & Didn't change \\
\hline 5 & Landslide & -6.9794 & 106.6039 & Cikadu & Didn't change \\
\hline 6 & Landslide & -6.9874 & 106.6079 & Cikadu & Changed \\
\hline 7 & Landslide & -6.9576 & 106.5633 & Cimanggu & Didn't change \\
\hline 8 & Landslide & -6.9688 & 106.5477 & Citepus & Changed \\
\hline 9 & Landslide & -6.9749 & 106.5419 & Citepus & Changed \\
\hline 10 & Landslide & -6.9844 & 106.6039 & Cikadu & Didn't change \\
\hline 11 & Landslide & -6.9739 & 106.5449 & Citepus & Didn't change \\
\hline 12 & Landslide & -6.9824 & 106.6019 & Cikadu & Didn't change \\
\hline 13 & Landslide & -6.9942 & 106.5994 & Cikadu & Didn't change \\
\hline 14 & Landslide & -6.968 & 106.537 & Citepus & Changed \\
\hline 15 & Landslide & -6.976 & 106.543 & Citepus & Changed \\
\hline 16 & Landslide & -6.9845 & 106.5476 & Palabuhanratu & Didn't change \\
\hline
\end{tabular}
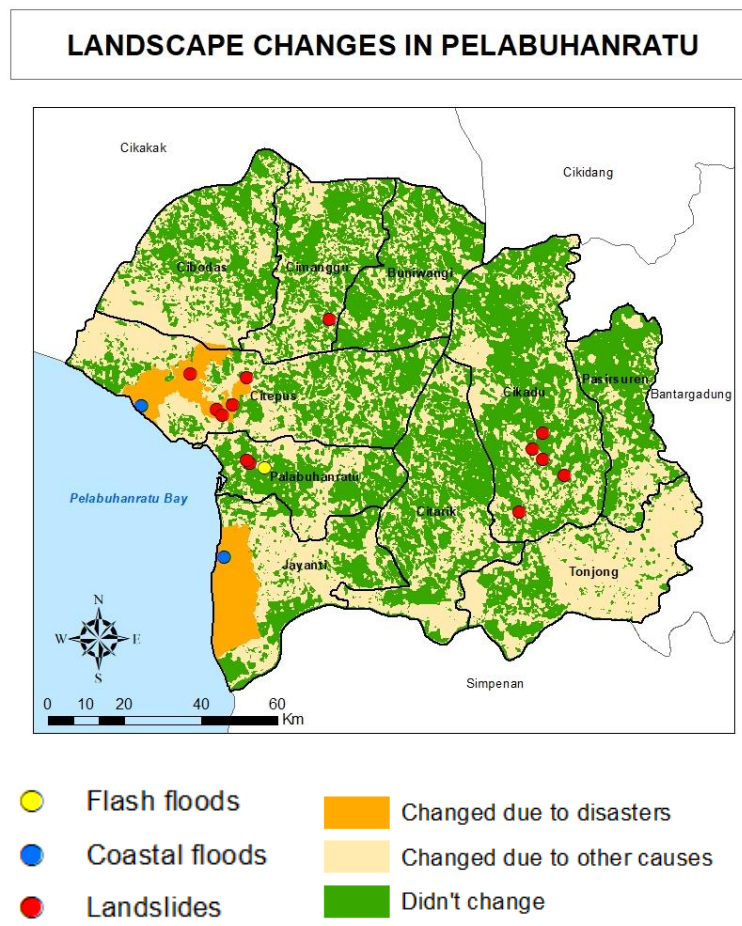

Fig. 2. Landscape changes in Pelabuhanratu.

\section{Conclusion}

Spatial approach using overlay analysis is suitable to be utilized in landscape studies. The coastal landscape characteristics of Pelabuhanratu City can be seen in the relationship between landforms and landcover. Most of the Pelabuhanratu District landscapes are volcanic land in the highlands with landform type volcano slope and the landcover is dominated by forests and scrubs. In the lowlands, the landscape that is formed is fluvial land with the shape of floodplains and the landcover is dominated by built-up lands and agricultural lands. Landscape changes that occurred from 2010 to 2018 mostly occurred in the amount of landcover area. Changes that occur are caused by several factors, including natural disasters and human activities. Some of landscape changes in Pelabuhanratu are caused by natural disasters, while the rest are caused by human activities. Changes that were spotted are Floodplains/Built-up Lands into Floodplains/Agricultural Lands, and Volcanic Slopes/ Scrubs into Volcanic Slopes/Agricultural Lands.

\section{References}

1. J. A. Zinck, The Geomorphic Landscape: Classification of Geoforms (Springer International Publishing Switzerland, 2016)

2. J. Duncan, Landscape Geography (Progress in Human Geography, 1993)

3. L. Brabyn, Landscape Classification Using GIS and National Digital Databases, 21 (1996)

4. C. J. Crossland, H. H. Kremer, H. Lindeboom, H., J. I. M. Clossland, M. D. A. Le Tissier, Global 
Change-the IGPB Series: Coastal Fluxes in the Anthropocene (Springer, Berlin, 2006)

5. D. G. Bengen, Ekosistem dan sumberdaya alam pesisir dan laut serta prinsip pengelolaannya (Institut Pertanian Bogor, Bogor, 2002)

6. A. M. Martĩnez-Grańa, P. G. Silva, J. I. Goy, J. Elez, V. Valdés, C. Zaco, Geomorphology applied to Landscape analysis for planning and management of natural spaces. Case study: Las Batuecas-S de Francia and Quilamas natural parks, (Salamanca, Spain), 584-585 (2017)

7. A. N. Strahler, Introduction to Physical Geography (Fourth Edition), (John Wiley \& Sons, Incorporated, 1975)

8. R. A. Van Zuidam, Aerial Photo-interpretation in Terrain Analysis and Geomorphologic Mapping, (The Hague, The Netherlands: Smits, 1985)

9. SNI (Standar Nasional Indonesia) No. 76451 (2014) 